\title{
Computational Prediction of the Effects of Single Nucleotide Polymorphisms of the Gene Encoding Human Endothelial Nitric Oxide Synthase
}

Esmaeil Samadian (MSc)

Department of Molecular Medicine,

Faculty of Advanced Medical

Technologies, Golestan University of

Medical Sciences, Gorgan, Iran

Ayyoob Khosravi (PhD)

Department of Molecular Medicine,

Scool of advanced Technologies in

Medicine, Golestan University of

Medical Sciences, Gorgan, Iran

Roghaye Gharae (MSc)

Laboratory Sciences Research Center,

Golestan University of Medical

Sciences, Gorgan, Iran

Mostafa Mir (MSc)

Department of Clinical Biochemistry, Faculty of medicine, Babol University of Medical Sciences, Babol, Iran

Sied Ahmad Sajjadi (MSc)

Reference Laboratory, Golestan University of Medical Sciences, Gorgan, Iran

Fahimeh Mohammad Abadi (MSc) Department of Clinical Biochemistry, Faculty of medicine, Gorgan University of Medical Sciences,

Gorgan, Iran

Nader Hashemi(MSc)

Department of Clinical Biochemistry

Faculty of medicine, Gorgan

University of Medical Sciences,

Gorgan, Iran

Sahar Alijanpour(MSc)

department of medical genetics,

Faculty of advanced medical

technologies, Golestan university of

medical sciences, Gorgan, Iran

Hamid Reza Joshaghani (PhD)

Laboratory Sciences Research Center, Golestan University of Medical

Sciences, Gorgan, Iran

Corresponding Author: Hamid Reza

Joshaghani

Email: joshaghani@goums.ac.ir

Tel: $+98(17) 32423093$

Adderess: Golestan University of

Medical Sciences, Gorgan, Iran

\section{ABSTRACT}

Introduction: Genetic variations in the gene encoding endothelial nitric oxide synthase (eN0S) enzyme affect the susceptibility to cardiovascular disease. Identification of the way these changes affect eNOS structure and function in laboratory conditions is difficult and time-consuming. Thus, it seems essential to perform bioinformatics studies prior to laboratory studies to find the variants that are more important. This study aimed to predict the damaging effect of changes in the coding region of eNOS using homology- and structurebased algorithms (SIFT and PolyPhen).

Methods: First, the single nucleotide polymorphisms in the coding region (cSNPs) of the human eNOS gene were extracted from dbSNP. Resulting amino acid changes were reported as primary data required for the study. Then, position and type of amino acid changes along with the complete amino acid sequence were separately entered into the SIFT and PolyPhen tools for analysis.

Results: 0f 144 single nucleotide changes, 30 changes by the SIFT, 47 changes by the PolyPhen and 18 amino acid substitutions by both tools were predicted as damaging.

Conclusion: It is predicted that 18 amino acid changes may have damaging phenotypic effects on the structure of the eNOS enzyme that may affect its performance by potentially affecting the enzyme's various functional regions. Therefore, computational prediction of potentially damaging nsSNPs and prioritizing amino acid changes may be useful for investigating protein performance using targeted re-sequencing and gene mutagenesis experiments.

Keywords: eN0S, Non-synonymous SNP, Functional impacts.

Received : 24 Jan 2014

Revised: 20 Feb 2014

Accepted: 23 Feb 2014

This paper should be cited as: Samadian S, Khosravi A, Gharae R, Mostafa M, Sajjadi SA, Mohammad Abadi F, Alijanpour S, Joshaghani HR[Computational Prediction of the Effects of Single Nucleotide Polymorphisms of the Gene Encoding Human Endothelial Nitric Oxide Synthase]. mljgoums. 2016; 10(3): 1-5 


\section{INTRODUCTION}

Nitric acid is a key factor in endothelial homeostasis, inhibition of platelet aggregation, adhesion of lymphocytes, which reduces proliferation and migration of smooth muscle cells and oxidation of LDL.

Several studies show that impaired nitric oxide (NO) pathway is involved in endothelial dysfunction and coronary artery disease (CAD) (1). Endothelial nitric oxide synthase (eNOS) is an enzyme responsible for the biosynthesis of NO in the endothelial tissue. Genetic changes in the eNOS encoding gene can affect expression levels, function of the enzyme and susceptibility to cardiovascular disease (2). Human eNOS is a $135 \mathrm{kDa}$ protein containing 1203 amino acids, encoded by the $21 \mathrm{kbp}$ NOS3 gene and 26 exons located on chromosome 7 (3).

Single nucleotide polymorphisms (SNPs) are the most common polymorphisms in the human genome (about 10 million) (4), and identification of polymorphisms that are responsible for the risk of complex human diseases is always achieved in the form of association studies.

Nowadays, in order to predict the effects of coding SNPs (cSNPs) associated with biological processes, tools such as sorting intolerant from tolerant (SIFT), polymorphism phenotyping (PolyPhen) and SNP 3D have been developed, which have made possible the prediction of damaging effect cSNPs and folding changes in the associated proteins (caused by amino acid change). These predictions are made either directly through 3D structural analysis or indirectly through sequence homology and amino acid evolutionary conservation level $(5,6)$.

The study of SNPs that result in amino acid changes (Missense SNPs) is the best way to estimate the effects of polymorphisms in the protein-coding region. These changes may directly affect structural stability of the protein or efficiency of its interactions. In this study, the damaging effect of SNPs in the proteincoding region of eNOS and phenotypic consequences of amino acid substitutions are estimated using protein sequence and structure information.

\section{MATERIAL AND METHODS}

cSNPs in the coding region of human eNOS gene was extracted from the dbSNP. Position and type of amino acid changes (AA1: amino acid in the normal protein, AA2: modified amino acids) and complete amino acid sequence of the respective protein were entered separately the SIFT and PolyPhen. These algorithms automatically predict the effect of each change in the protein levels in accordance with the criteria defined by the designers. All entries were matched with the database and if the position and type of changes in the protein were correct, the consequence of the amino changes were analyzed. After entering inputs of the SIFT and PolyPhen, these tools were run separately. SIFT is a sequence homology-based tool that scores the impact of each cSNP ranging from 0 to 1 (SIFT score). The cSNP is predicted damaging if the score is $\leq 0.05$, and tolerated if the score is $>0.05$. PolyPhen is a tool that predicts the effects of cSNPs using protein structure information at four levels of benign, possibly damaging, probably damaging and unknown (7).

\section{RESULTS}

Overall, 144 SNPs have been reported in the coding region of the eNOS gene in the SNP database considered as inputs for the SIFT and PolyPhen. The phenotypic effects of amino acid substitutions for all 144 changes were analyzed using the sequence homologybased software (SIFT). This tool predicted that 67 changes $(46.5 \%)$ are conserved during the evolution that can affect protein function. Among these changes, 38 (26.3\%) amino acid substitutions (with a score of zero) are highly conserved, thus can apply the most phenotypic effects on protein levels. SIFT predicted the other 77 (53.4\%) substitutions as nondamaging (Table 1). In the PolyPhen output, $47(32.6 \%)$ changes were probably damaging, $29(20.1 \%)$ were possibly damaging and 68 (47.2\%) changes were predicted as benign. Among the 38 amino acid substitutions identified by SIFT as probably damaging, 18 $(47.3 \%)$ were also found to affect extremely protein structure according to the PolyPhen tool. 
Table 1- Predicting the effects of nsSNPs of the human eNOS gene using SIFT and PolyPhen

\begin{tabular}{|c|c|c|c|c|c|c|}
\hline PolyPhen score & $\begin{array}{l}\text { PolyPhen } \\
\text { prediction }\end{array}$ & $\begin{array}{l}\text { SIFT } \\
\text { score }\end{array}$ & SIFT prediction & $\begin{array}{l}\text { Substitution } \\
\text { position }\end{array}$ & $\begin{array}{l}\text { Amino acid } \\
\text { substitution }\end{array}$ & SNP ID \\
\hline 2.147 & $\begin{array}{l}\text { probably } \\
\text { damaging }\end{array}$ & 0.00 & DAMAGING & 287 & $\begin{array}{l}\text { D [Asp] } \\
\mathbf{N} \text { [Asn] }\end{array}$ & rs149539813 \\
\hline 2.449 & $\begin{array}{l}\text { probably } \\
\text { damaging }\end{array}$ & 0.00 & DAMAGING & 438 & $\begin{array}{l}R[\text { Arg] } \Rightarrow S \\
{[\text { Ser }]}\end{array}$ & rs148991283 \\
\hline 2.673 & $\begin{array}{l}\text { probably } \\
\text { damaging }\end{array}$ & 0.00 & DAMAGING & 944 & $\begin{array}{l}\mathbf{S}[\mathrm{Ser}] \Rightarrow \mathbf{L} \\
{[\mathbf{L e u}]}\end{array}$ & rs61747096 \\
\hline 0.961 & $\begin{array}{l}\text { probably } \\
\text { damaging }\end{array}$ & 0.00 & DAMAGING & 921 & $\begin{array}{l}\text { V [Val] } \Rightarrow \text { G } \\
{[\text { Gly }]}\end{array}$ & rs74962429 \\
\hline 1.000 & $\begin{array}{l}\text { probably } \\
\text { damaging }\end{array}$ & 0.00 & DAMAGING & 1022 & $\begin{array}{l}R \text { [Arg] } \Rightarrow \\
W \text { [Trp] }\end{array}$ & rs140510569 \\
\hline 0.999 & $\begin{array}{l}\text { probably } \\
\text { damaging }\end{array}$ & 0.00 & DAMAGING & 549 & $\begin{array}{l}R \text { [Arg] } \Rightarrow \\
W \text { [Trp] }\end{array}$ & rs142781987 \\
\hline 1.000 & $\begin{array}{l}\text { probably } \\
\text { damaging }\end{array}$ & 0.00 & DAMAGING & 941 & $\begin{array}{l}\mathbf{S}[\text { Ser }] \Rightarrow \mathbf{L} \\
{[\mathbf{L e u}]}\end{array}$ & rs144452379 \\
\hline 1.000 & $\begin{array}{l}\text { probably } \\
\text { damaging }\end{array}$ & 0.00 & DAMAGING & 1172 & $\begin{array}{l}R[\operatorname{Arg}] \Rightarrow C \\
{[\text { Cys }]}\end{array}$ & \\
\hline 1.000 & $\begin{array}{l}\text { probably } \\
\text { damaging }\end{array}$ & 0.00 & DAMAGING & 854 & $\begin{array}{l}\text { T }[\mathrm{Thr}] \Rightarrow \mathbf{M} \\
{[\text { Met }]}\end{array}$ & $\begin{array}{l}\text { rs146141837 } \\
\text { rs148919189 }\end{array}$ \\
\hline 1.000 & $\begin{array}{l}\text { probably } \\
\text { damaging }\end{array}$ & 0.00 & DAMAGING & 255 & $\begin{array}{l}R \quad[\operatorname{Arg}] \Rightarrow \\
W \text { [Trp] }\end{array}$ & rs200161933 \\
\hline 1.000 & $\begin{array}{l}\text { probably } \\
\text { damaging }\end{array}$ & 0.00 & DAMAGING & 357 & $\begin{array}{l}\text { Y [Tyr] } \Rightarrow D \\
{[\text { Asp] }}\end{array}$ & rs201023253 \\
\hline 0.997 & $\begin{array}{l}\text { probably } \\
\text { damaging }\end{array}$ & 0.00 & DAMAGING & 506 & $\begin{array}{l}\mathbf{S}[\text { Ser }] \Rightarrow \mathbf{F} \\
{[\text { Phe }]}\end{array}$ & rs201216025 \\
\hline 1.000 & $\begin{array}{l}\text { probably } \\
\text { damaging }\end{array}$ & 0.00 & DAMAGING & 944 & $\begin{array}{l}\mathbf{S}[\mathrm{Ser}] \Rightarrow \mathbf{P} \\
{[\text { Pro }]}\end{array}$ & rs367558109 \\
\hline 1.000 & $\begin{array}{l}\text { probably } \\
\text { damaging }\end{array}$ & 0.00 & DAMAGING & 795 & $\begin{array}{l}\mathbf{P}[\text { Pro] } \Rightarrow \mathbf{L} \\
{[\mathbf{L e u}]}\end{array}$ & rs368180942 \\
\hline 1.000 & $\begin{array}{l}\text { probably } \\
\text { damaging }\end{array}$ & 0.00 & DAMAGING & 250 & $\begin{array}{l}R[\text { Arg }] \Rightarrow C \\
{[\text { Cys }]}\end{array}$ & rs368296624 \\
\hline 1.000 & $\begin{array}{l}\text { probably } \\
\text { damaging }\end{array}$ & 0.00 & DAMAGING & 149 & $\begin{array}{l}\mathrm{R}[\mathrm{Arg}] \Rightarrow \mathbf{Q} \\
{[\mathbf{G l n}]}\end{array}$ & rs368889481 \\
\hline 0.998 & $\begin{array}{l}\text { probably } \\
\text { damaging }\end{array}$ & 0.00 & DAMAGING & 350 & $\begin{array}{l}\text { A [Ala] } \Rightarrow \text { T } \\
{[\text { Thr] }}\end{array}$ & rs376007167 \\
\hline 0.996 & $\begin{array}{l}\text { probably } \\
\text { damaging }\end{array}$ & 0.00 & DAMAGING & 185 & $\begin{array}{l}\mathbf{V}[\text { Val }] \Rightarrow M \\
{[\text { Met }]}\end{array}$ & rs377756718 \\
\hline
\end{tabular}

These substitutions may affect the function of human eNOS enzyme by affecting its various functional regions. Position of the substitutions and some of their functional regions in this protein have been identified (Table 2).

Table 2- Position of completely damaging substitutions in the eNOS protein

\begin{tabular}{|c|c|c|}
\hline $\begin{array}{l}\text { Completely damaging } \\
\text { damaging substitutions }\end{array}$ & Length of functional regions & Functional regions \\
\hline R549W & $520-573$ & Flavodoxin-like domain \\
\hline $\begin{array}{l}\text { P795L، S944P، T854M، S941L، V921G، } \\
\text { S944L }\end{array}$ & $756-1002$ & $\begin{array}{l}\text { Ferredoxin reductase-type FAD-binding } \\
\text { domain }\end{array}$ \\
\hline $\begin{array}{l}\text { D287N ، R438S، V185M R250C، Y357D، } \\
\text { R149Q R255W،A350T }\end{array}$ & $98-486$ & $\begin{array}{l}\text { Interaction with the enzyme inhibitor } \\
\text { (NOSIP) }\end{array}$ \\
\hline $\begin{array}{l}\text { S506F } \\
\text { R1022W }\end{array}$ & $\begin{array}{l}\text { 491-510 } \\
-\end{array}$ & $\begin{array}{l}\text { Calmodulin binding domain } \\
\text { Unknown }\end{array}$ \\
\hline R1172C & - & Unknown \\
\hline
\end{tabular}




\section{DISCUSSION}

Coronary Artery Disorder (CAD) is the most common cardiovascular cause of death worldwide. The inner lining of the arteries plays an important role in the process of this disease by releasing mediators such as NO (1). Several studies in recent years demonstrated the important role of the eNOS enzyme in biological processes. SNPs in the coding region of the enzyme may affect its performance and cause genetic disorders such as cardiovascular disease in humans (5). Given that the single nucleotide changes are the most common changes in the human genome, association studies of the changes in the selected genes involved in the pathogenesis of human diseases, especially the eNOS gene could be useful for better understanding the role of these changes. Moreover, in silico studies have recently attracted the attention of many researchers due to increasing number of data in databases such as dbSNP and the impossibility of screening all genetic changes in laboratory conditions (8). The easiest and most common strategy used in such studies is limited to markers located in the coding region of selected genes (linked to the desired trait). By selecting this direct approach, less SNPs are studied as probable main polymorphisms (9). These studies are capable of predicting the phenotypic effects of changes in the gene encoding the protein using information available in proteins' sequence or structure (10-12). Based on the results, most SNPs in the human eNOS gene occur in the interaction domain with the enzyme inhibitor (NOSIP) (D287N，R438S, V185M R250C, Y357D, R149Q R255W, A350T) that can affect the interaction of this enzyme with its inhibitor (NOSIP). Moreover, FAD-binding domain of this enzyme may become affected by the P795L، S944P، T854M، S941L، V921G and

S944L substitutions. R549W and S506F substitutions may also affect the functional regions of the protein by affecting the flavodoxin-like and calmodulin binding domains, respectively. This prediction showed that $\mathrm{R} 1022 \mathrm{~W}$ and $\mathrm{R} 1172 \mathrm{C}$ substitutions are extremely damaging, and amino acids in these positions are of great importance from the evolutionary perspective. This indicates the presence of a particular domain, motif or functional region that is not yet known.

Several studies have shown that glutamic acid to aspartic acid change at position 298 can affect the primary structure of the enzyme (13); therefore, many studies have reported this position as the factor associated with the increased risk of various diseases, especially CAD (13-18). This change occurs in the nitric oxide synthase interacting region of the protein (NOSIP). In the present study, the most damaging single nucleotide changes have been predicted in this region.

\section{CONCLUSION}

It is predicted that 18 amino acid changes may have damaging phenotypic effects on the structure of the eNOS enzyme that may affect its performance by potentially affecting the enzyme's various functional regions. It is thus possible that the impaired vascular endothelial function affects the pathogenesis of CAD.

\section{ACKNOWLEDGEMENTS}

The authors would like to thank the colleagues in the faculty of Paramedical Sciences of Golestan University of Medical Sceinces and Mr. Seyed Hossein Sadeghi for their help. This Project has been funded by the Golestan University of Medical Sciences Research Committee (Project No. 9012020232).

\section{CONFLICT OF INTEREST}

All contributing authors declare no conflicts of interest. 


\section{REFERENCES}

1. Kim IJ, Bae J, Lim SW, Cha DH, Cho HJ, Kim S, et al. Influence of endothelial nitric oxide synthase gene polymorphisms $(-786 \mathrm{~T}>\mathrm{C}, 4 \mathrm{a} 4 \mathrm{~b}, 894 \mathrm{G}>\mathrm{T})$ in Korean patients with coronary artery disease. Thrombosis research. 2007;119(5):579-85.

2. Hingorani AD .Polymorphisms in endothelial nitric oxide synthase and atherogenesis: John French Lecture 2000. Atherosclerosis. 2001;154(3):521-7.

3. Marsden PA, Heng H, Scherer S, Stewart R, Hall A, Shi X, et al. Structure and chromosomal localization of the human constitutive endothelial nitric oxide synthase gene. Journal of biological chemistry. 1993;268(23): 17478-88

4. Kruglyak L, Nickerson DA. Variation is the spice of life. Nature genetics. 2001; 27(3): 234-5.

5. Kerkeni M, Addad F, Chauffert M, Myara A, Farhat MB, Miled A, et al. Hyperhomocysteinemia, endothelial nitric oxide synthase polymorphism, and risk of coronary artery disease. clinical chemistry. 2006; 52(1): 53-8.

6. Nakken S, Alseth I, Rognes T. Computational prediction of the effects of non-synonymous single nucleotide polymorphisms in human DNA repair genes. Neuroscience. 2007; 145(4): 1273-9.

7. Naderi M GR, Soleymani-Nejadian E, Samadian E. In Silico survey of functional coding variants in human AEG-1 gene. Egyptian Journal of Medical Human Genetics. 2013; 14(4): 419-22.

8. Ramensky V, Bork P, Sunyaev S. Human nonsynonymous SNPs: server and survey. Nucleic acids research. 2002; 30(17): 3894-900.

9. Hummelshøj T, Munthe-Fog L, Madsen HO, Garred P. Functional SNPs in the human ficolin (FCN) genes reveal distinct geographical patterns. Molecular immunology. 2008; 45(9): 2508-20. doi: 10.1016/j.molimm.2008.01.003.

10. Doss CGP, Rao S. Impact of single nucleotide polymorphisms in $H B B$ gene causing haemoglobinopathies: in silico analysis. New biotechnology. 2009; 25(4): 214-9. doi: 10.1016/j.nbt.2009.01.004.
11. Wang L-L, Li Y, Zhou S-F. Prediction of deleterious non-synonymous single nucleotide polymorphisms of genes related to ethanol-induced toxicity. Toxicol Lett. 2009; 187(2): 99-114. doi: 10.1016/j.toxlet.2009.02.007. 12. Shi Z, Moult J. Structural and functional impact of cancer-related missense somatic mutations. Journal of molecular biology. 2011; 413(2): 495-512.

13. Angeline T, Isabel W, Tsongalis GJ. Endothelial nitric oxide gene polymorphisms, nitric oxide production and coronary artery disease risk in a South Indian population. Experimental and molecular pathology. 2010; 89(3): 205-8. doi: 10.1016/j.yexmp.2010.08.009.

14. Jaramillo PC, Lanas C, Lanas F, Salazar LA. Polymorphisms of the NOS3 gene in Southern Chilean subjects with coronary artery disease and controls. Clinica Chimica Acta. 2010; 411(3): 258-62. doi: 10.1016/j.cca.2009.11.018.

15. Jaramillo PC, Muñoz A ,Lanas C, Lanas F, Salazar LA. Endothelial nitric oxide synthase G894T gene polymorphism in Chilean subjects with coronary artery disease and controls. Clinica Chimica Acta. 2006; 371(1): 102-6. doi:10.1016/j.cca.2006.02.030.

16. Berdeli A, Sekuri C, Cam FS, Ercan E, Sagcan A, Tengiz I, et al. Association between the eNOS (Glu298Asp) and the RAS genes polymorphisms and premature coronary artery disease in a Turkish population. Clinica Chimica Acta. 2005; 351(1): 87-94.

17. Xiang Y, Dong Y, Li X, Tang X. Association of Common Variants in eNOS Gene with Primary Open Angle Glaucoma: A Meta-Analysis. Journal of ophthalmology. 2016; 2016: 1348347. doi.org/10.1155/2016/1348347.

18. Luo JQ, Wen JG, Zhou HH, Chen XP, Zhang W. Endothelial nitric oxide synthase gene G894T polymorphism and myocardial infarction: a metaanalysis of 34 studies involving 21,068 subjects. PLoS $\begin{array}{llll}\text { One. } & \text { 2014; } & \text { 9(1): } & \text { e87196. doi: }\end{array}$ 10.1371/journal.pone.0087196. eCollection 2014. 